\title{
THE OXYGEN UPTAKE OF SUSPENSIONS AND CULTURES OF A FREE-LIVING BACTERIUM
}

\author{
By JANE MEIKLEJOHN
}

(Department of General Microbiology, Rothamsted Experimental Station)

(Received 21 September 1936)

(With Four Text-figures)

\section{INTRODUCTION}

THE study of the metabolic processes taking place in a growing culture of microorganisms presents some particular difficulties, and, in consequence, comparatively little work along these lines has as yet been reported. Among earlier papers on this subject, the following may be mentioned. The course of events during the growth cycle of a single culture has been investigated by Walker $\&$ Winslow and their associates (1932, 1934), who measured the carbon dioxide output and ammonia production (from peptone) of a pure culture of $B$. coli. Martin (1932), using the same organism, has made continuous studies of the oxygen uptake throughout its growth cycle; he found a pronounced maximum in the oxygen uptake per cell, occurring at the end of the lag period, or early in the logarithmic growth period, which he was able to associate with the time of maximum cell size. Burk $\&$ Lineweaver (1930), in the course of their intensive studies on the metabolism of Azotobacter, compared the constant rate of respiration of a non-growing culture (deprived of nitrogen) with the increasing rate of a growing culture.

In the study of the metabolism of a growing culture, the use of a free-living organism, which can be grown at a temperature of $25^{\circ} \mathrm{C}$. or so, presents certain definite advantages over the use of a pathogenic strain. As the growth cycle is spread over a longer period, $4^{-6}$ days, instead of as many hours at $37^{\circ}$, it is possible to obtain a more detailed picture of the events at each stage of growth.

In the present study, the oxygen uptake of a free-living bacterial species, derived ultimately from soil, and used in pure culture, was studied by means of Barcroft differential manometers. Two sets of experiments were carried out; in the first set, single observations were made on small amounts of liquid medium heavily inoculated with bacteria; these are referred to as suspension experiments throughout this paper. In the second set, referred to as culture experiments, a large volume of medium was seeded with a small inoculum of the bacteria in each case, and the resulting culture was observed at intervals up to the peak stationary phase of growth. 


\section{Description of species}

The bacterial species employed in these experiments was one of a number isolated, in the course of investigations on the purification of effluent from a beet-sugar factory, by the General Microbiology Department at Rothamsted. It was obtained from the film on a gravel filter used in this work, and was probably originally derived from the soil washed off the beets, which was the principal source of inoculation of the filter. In the present state of classification of the saprophytic bacteria, it is impossible to assign a specific name to it; it resembles in some respects the description given in Bergey's Manual (1934) for Achromobacter fermentationis (Chester), but differs from it in not coagulating milk in 7 days. Its cultural characteristics are as follows: rods- $\mathrm{I} \cdot 0 \mu \times 0.8 \mu$, non-motile, non-spore forming, gram negative; agar streak-growth good, filiform, white, opalescent, smooth, edge undulate, medium unchanged; colonies on Thornton's agar-round, white, slightly convex, opalescent. Does not liquefy gelatine. Produces acid and gas on sucrose and levulose, acid on dextrose, maltose and mannitol, acid and gas on glycerine. Reduces nitrates to nitrites. Forms acid on litmus milk, no coagulation or digestion. Aerobic, facultative.

\section{Method of counting}

The bacteria were counted throughout by the direct method, using a Thoma haemocytometer, $0.02 \mathrm{~mm}$. deep, with $\mathrm{r} / 400 \mathrm{~mm} .^{2}$ squares. Duplicate counts were made in every case. This method of counting includes all bacterial cells present, whether viable or not.

\section{Measurement of oxygen uptake}

The apparatus used for the measurement of oxygen uptake consisted of Barcroft differential manometers; the technique employed has been fully described by Dixon (I934). The volume of sample used was 3 c.c. of the liquid culture, or suspension, in every case. The measurements were made at a temperature of $26^{\circ} \mathrm{C}$., and $\mathrm{KOH}$ solution on filter paper was used to absorb carbon dioxide.

Estimations of the respiratory quotient (carbon dioxide evolved/oxygen absorbed) were made by the technique described by Dixon (1934), in which one manometer is used to measure oxygen uptake, one (without $\mathrm{KOH}$ paper) to measure the difference between oxygen uptake and carbon dioxide evolution, and a third to measure the amount of bound carbon dioxide in the medium. This method gives an approximate estimate only of the respiratory quotient.

\section{SUSPENSION EXPERIMENTS}

\section{Methods}

In these experiments, heavy suspensions of young cells were made by washing off the surface growth from cultures on a solid medium into a liquid medium containing either alanine (carbon and nitrogen both supplied) or glucose (carbon only).

The bacteria were grown on nutrient agar; one, two or three tubes of this medium (according to the thickness of suspension desired) were inoculated and grown at $22^{\circ} \mathrm{C}$. for either 24 or 48 hours. 0.5 c.c. of the liquid medium was then poured on to the surface 
of each slope with a sterile pipette, and the surface growth emulsified in this liquid with a loop; the emulsion was pipetted into Io c.c. of sterile medium to form the suspension used. The number of bacterial cells in the suspension was counted in duplicate at the beginning and end of the experiment. The oxygen uptake of two samples of the suspension was measured over a period of 6 hours.

\section{Media}

The following liquid media were used:

(a) Glucose medium (contains no nitrogen).

0.2 per cent glucose and 0.12 per cent $\mathrm{KH}_{2} \mathrm{PO}_{4}$ in a mineral salt solution of the following composition: $\mathrm{NaCl} 0.06$ per cent, $\mathrm{KCl} 0.00 \mathrm{I}$ per cent, $\mathrm{CaCl}_{2} 0.002$ per cent, $\mathrm{MgSO}_{4} 0.00 \mathrm{I}$ per cent. Steamed for I hour, $p \mathrm{H}$ adjusted to $7 \cdot 2$ with $N /$ io $\mathrm{NaOH}$, steamed again for $\mathrm{I}$ hour.

(b) Alonine medium.

As above, except that the glucose was replaced by 0.2 per cent of alanine ( $\alpha$-aminopropionic acid).

\section{Results}

The results obtained from twelve experiments with the alanine medium showed two constant differences from the ten experiments with the glucose medium, which are illustrated in Table I. This table summarizes the results from six typical experiments, arranged in pairs, each pair consisting of one alanine suspension and one glucose suspension, with approximately equal bacterial numbers at the start of the experiment.

Table I

\begin{tabular}{|c|c|c|c|c|}
\hline \multirow[b]{2}{*}{$\begin{array}{c}\text { Time from } \\
\text { start } \\
\text { (hr.) }\end{array}$} & \multicolumn{2}{|c|}{ Alanine } & \multicolumn{2}{|c|}{ Glucose } \\
\hline & $\begin{array}{c}\text { Bacterial nos. } \\
\text { (millions per c.c.) }\end{array}$ & $\begin{array}{c}\text { Rate of oxygen } \\
\text { uptake per } \\
\frac{1}{3} \text { hour } \\
\text { (mm. from } 3 \text { c.c.) }\end{array}$ & $\begin{array}{c}\text { Bacterial nos. } \\
\text { (millions per c.c.) }\end{array}$ & $\begin{array}{c}\text { Rate of oxygen } \\
\text { uptake per } \\
\frac{1}{2} \text { hour } \\
\text { (mm. }{ }^{3} \text { from } 3 \text { c.c.) }\end{array}$ \\
\hline 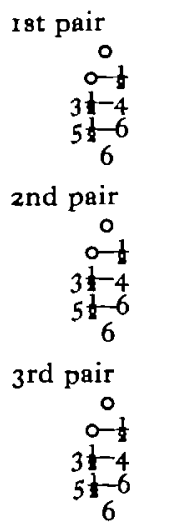 & $\begin{array}{l}\frac{4^{62}}{-} \\
\overline{1200} \\
\frac{884}{-} \\
\overline{2240} \\
1026 \\
= \\
2660\end{array}$ & $\begin{array}{r}- \\
15 \\
55 \\
94 \\
- \\
- \\
35 \\
80 \\
150 \\
- \\
- \\
49 \\
112 \\
161 \\
-\end{array}$ & $\begin{array}{l}\underline{434} \\
\bar{Z} \\
380 \\
\frac{926}{Z} \\
\text { 1163 } \\
1060 \\
\frac{-}{1038}\end{array}$ & $\begin{array}{l}\overline{6} \\
9 \\
7 \\
- \\
39 \\
33 \\
27 \\
\\
36 \\
29 \\
27 \\
\end{array}$ \\
\hline
\end{tabular}


The first difference between the suspensions on alanine and those on glucose is that a considerable increase in bacterial numbers takes place on the first medium, but not on the second. The second difference is that the rate of oxygen uptake rises markedly and continuously in the alanine suspensions, but falls a little with time in the glucose suspensions. This is further illustrated in Fig. I, which shows the rate of oxygen uptake for each half hour during the whole course of the second pair of experiments in the table. The curve obtained from the alanine suspension is concave upwards; a similar curve was obtained from all the alanine experiments, and its nature can be seen if the logarithms of the respiration rates are plotted against time. Fig. 2 shows the logarithms of the rates of oxygen uptake derived from two alanine experiments ( 4 and 9). The observed points in experiment 4 fall very nearly on a straight line; the rate of oxygen uptake is increasing logarithmically throughout. In other cases, however (as in experiment 9), there seems to be a preliminary period of adjustment, after which the rate increases logarithmically.

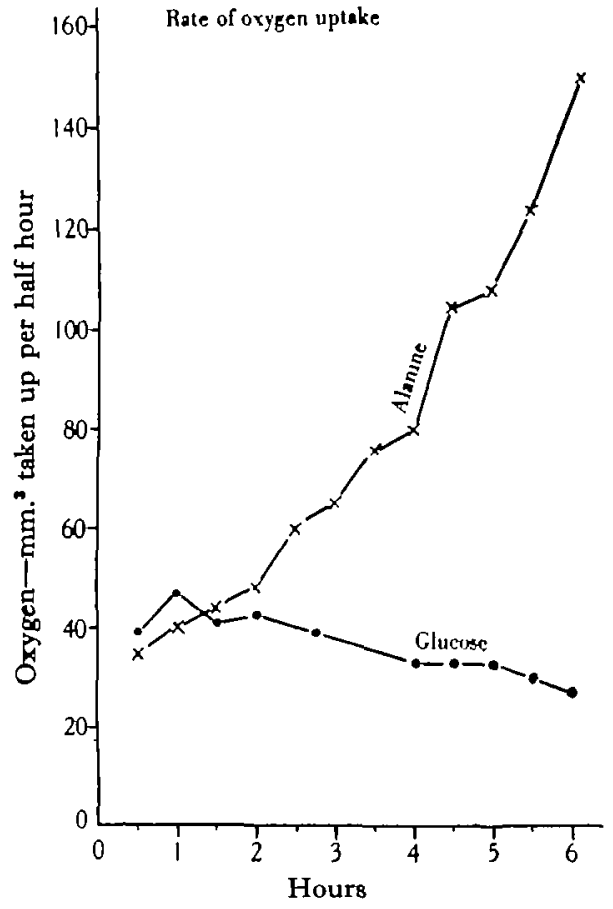

Fig. I. The rates of oxygen uptake per half hour in a pair of suspensions containing about 900 million bacteria perc.c. at the start.

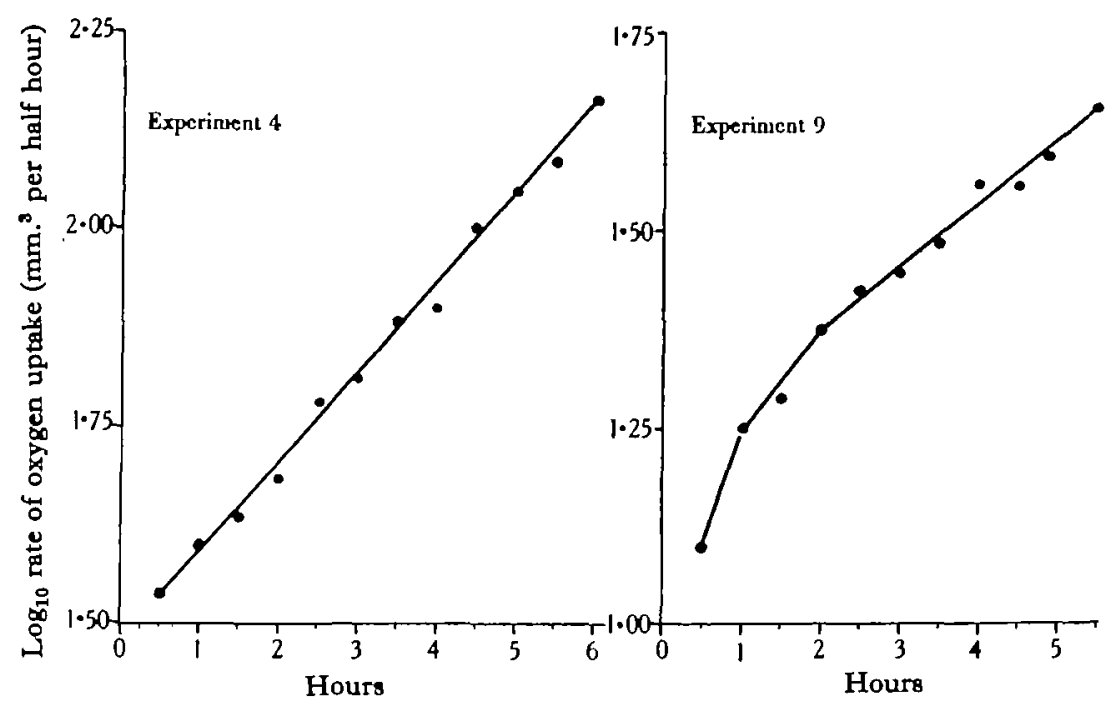

Fig. 2. Logarithms of the respiration rates in two suspensions on alanine. 


\section{RELATION BETWEEN GROWTH AND INCREASE IN RESPIRATION RATE}

As the increase in respiration rate has been used by Burk \& Lineweaver (1930) as a measure of bacterial growth, it is of interest to see whether in these experiments the increase in the rate of oxygen uptake corresponds with the increase in bacterial numbers. If the respiration rate increases during the experiment in proportion with the increase in bacterial numbers, then the rate of respiration per cell should be the same at the end of the experiment as at the beginning. In Table II are given the rates of oxygen uptake per $\frac{1}{2}$ hour from 3 c.c., and the rate per hour per rooo million bacteria for the first half hour and the last half hour of eight experiments on the alanine medium.

Table II

\begin{tabular}{|c|c|c|c|c|c|c|}
\hline \multirow[b]{2}{*}{ Exp. } & \multicolumn{3}{|c|}{ Start } & \multicolumn{3}{|c|}{ Finish } \\
\hline & $\begin{array}{l}\text { Number of } \\
\text { bacteria } \\
\text { (millions } \\
\text { per c.c.) }\end{array}$ & $\begin{array}{c}\text { Rate per } \\
\frac{1}{g} \text { hour } \\
\left(\mathrm{mm}_{i}^{3}\right)\end{array}$ & $\begin{array}{l}\text { Rate per hr. } \\
\text { per IOOO } \\
\text { million }\end{array}$ & $\begin{array}{c}\text { Number of } \\
\text { bacteria } \\
\text { (millions } \\
\text { per c.c.) }\end{array}$ & $\begin{array}{c}\text { Rate per } \\
\frac{1}{t} \text { hour } \\
\text { (mm. })\end{array}$ & $\begin{array}{c}\text { Rate per hr. } \\
\text { per 1000 } \\
\text { million }\end{array}$ \\
\hline $\begin{array}{l}1 \\
2 \\
3 \\
4 \\
5 \\
6 \\
7 \\
8\end{array}$ & $\begin{array}{r}1026 \\
462 \\
520 \\
884 \\
1302 \\
450 \\
834 \\
624\end{array}$ & $\begin{array}{l}49 \\
15 \\
20 \\
35 \\
45 \\
22 \\
34 \\
32\end{array}$ & $\begin{array}{l}34 \\
31 \\
30 \\
28 \\
23 \\
36 \\
30 \\
38\end{array}$ & $\begin{array}{l}2660 \\
1200 \\
1508 \\
2240 \\
2460 \\
1445 \\
1970 \\
1980\end{array}$ & $\begin{array}{r}161 \\
94 \\
95 \\
150 \\
137 \\
99 \\
154 \\
157\end{array}$ & $\begin{array}{l}41 \\
49 \\
40 \\
41 \\
37 \\
48 \\
48 \\
49\end{array}$ \\
\hline
\end{tabular}

In every case the rate of oxygen uptake per 1000 million cells is larger at the end of the experiment than at the beginning; the increase in respiration rate is greater proportionately than the increase in bacterial numbers. It is possible to consider the total oxygen uptake of such an actively growing suspension as divisible into two parts-(a) "maintenance" respiration, directly proportional to the number of bacteria present in the suspension, and therefore increasing during the experimental period, but insufficient to account for the total increase in respiration rate of the culture; and $(b)$ "growth" respiration in the strict sense, presumably proportional to the division rate of the cells at any time.

\section{Respiratory quotient}

Nine estimations of the respiratory quotient were made on the glucose, and nine on the alanine medium; the R.Q. in both cases was a little less than unity. The glucose experiments gave a mean value of 0.88 (standard error \pm 0.013 ), and the alanine experiments a mean value of 0.93 (standard error \pm 0.017 ).

\section{CULTURE EXPERIMENTS}

\section{METHODS}

In these experiments an effort was made to follow the course of events during a complete growth cycle, in cultures started with a small inoculum, by successive counts, and measuring the oxygen uptake of samples taken at intervals up to 24 hours apart. 


\section{Oxygen Uptake of Suspensions and Cultures of a Free-living Bacterium I63 \\ Medium}

The medium used throughout was the alanine medium described in section $I$; 60 c.c. of this liquid medium, in a sterile 250 c.c. conical flask, were used in each experiment.

\section{Inoculations}

Two loopfuls of the growth from a young agar slope culture (18-30 hours old, usually 24 hours) were emulsified in Io-20 c.c. of sterile medium in a small flask. The cells in the resulting suspension were counted with a haemocytometer, and $1-3$ c.c. of the suspension were added to the culture flask, to give an initial count of between 5 and 10 million cells per c.c. This method has been found to give more consistent results than direct inoculation of the culture flask.

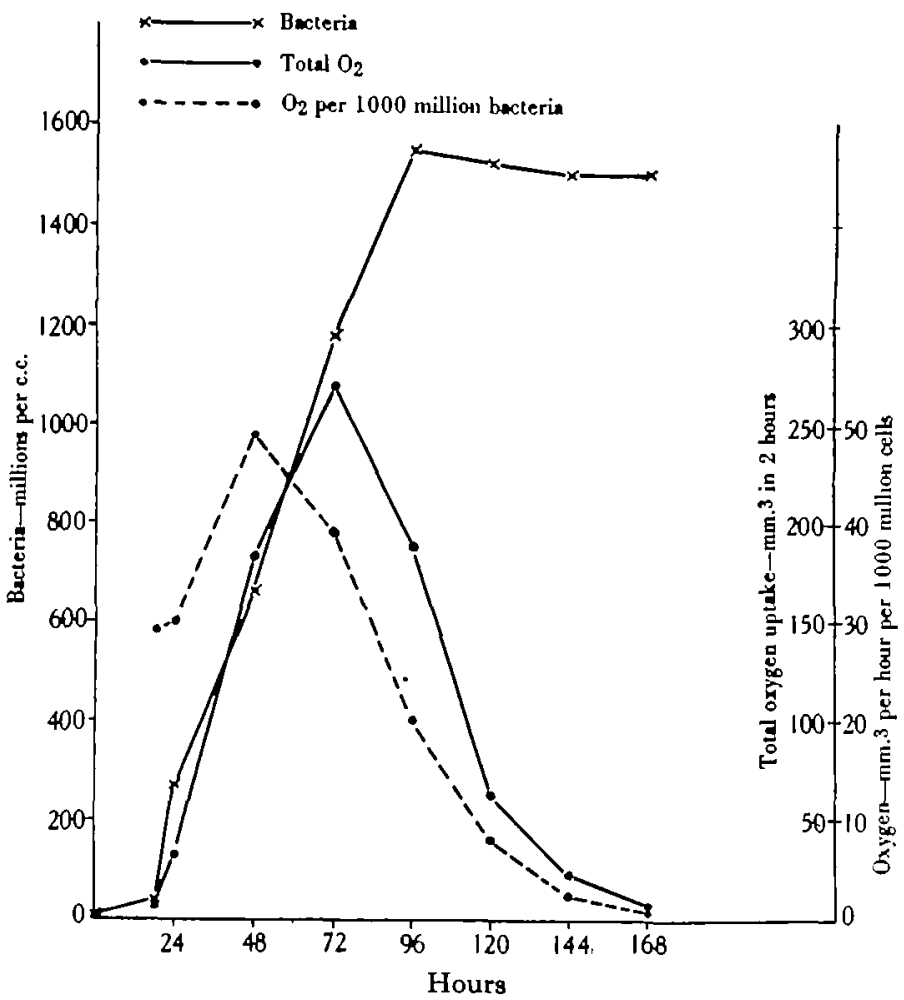

Fig. 3. Course of events in a growing culture.

\section{Sampling}

The culture flasks, plugged with cotton wool, were suspended in a water bath at a temperature of about $25^{\circ} \mathrm{C}$. $\left( \pm 0.5^{\circ}\right)$. No attempt was made to aerate the cultures. They were maintained for periods up to 7 days from the inoculation, and, at daily or shorter intervals, samples were withdrawn, the numbers of bacteria in them counted, and their oxygen uptake measured over a.period of 2 hours.

\section{RESULTS}

The course of events occurring in a culture under the given conditions is illustrated by Fig. 3, which represents the average figures derived from six experiments performed under identical conditions, and giving closely similar results. It 
will be seen that the numbers of bacteria present in the cultures increased up to 96 hours after inoculation, when a steady state was reached at about 1500 million cells per c.c. The total oxygen taken up in a 2 -hour period attained a maximum value of about $270 \mathrm{~mm}{ }^{3}$ in samples taken from 72 -hour-old cultures; samples from older cultures gave values for total oxygen uptake decreasing rapidly with age, till, a week after inoculation (and 3 days after the stationary state was attained), the oxygen uptake was so small as to be only just measurable. Similar results were obtained for $\mathrm{CO}_{2}$ output by Walker \& Winslow (1932). The oxygen uptake per cell (calculated as the oxygen uptake per hour per 1000 million bacteria) reaches a maximum value in samples taken 48 hours after inoculation, during the early part of the logarithmic growth period. On account of the smallness of the organism employed, it was impossible to measure any but the grossest variations in the size of individual cells; large variations in size were not observed, so the maximum value of oxygen uptake per cell cannot be definitely connected with the time of maximum cell size (cf. Martin, 1932).

\section{RESPIRATORY QUOTIENT}

A few estimations of the respiratory quotient, made at different times in the growth cycle, gave values of unity or slightly_below in nearly every case. The figures are given in Table III, which also shows the progressive increase, with the age of the culture, in bound $\mathrm{CO}_{2}$ present in the medium.

Table III. Respiratory quotient and bound $\mathrm{CO}_{2}$

$\begin{array}{lcccc}\text { Age of culture } & 24 \text { hours } & 48 \text { hours } & 72 \text { hours } & 96 \text { hours } \\ \text { R.Q. (av.) } & 0 \cdot 95 & 1 \cdot 0 & 0.97 & 0.91 \\ \text { Bound CO, (av.) (mm. }{ }^{2} \text { in } 3 \text { c.c.) } & 75 & 134 & 233 & 340^{\circ}\end{array}$

\section{COURSE OF OXYGEN UPTAKE IN INDIVIDUAL SAMPLES}

The course of oxygen uptake in 2 hours from samples taken at intervals of 24 hours in a single experiment is illustrated in Fig. 4, which gives the rate of oxygen uptake for each $\frac{1}{1}$ hour (mean values from duplicate samples). The oxygen uptake of the sample taken 24 hours after inoculation is very small, and proceeds at a nearly constant rate. On the other hand, the large oxygen uptakes of the 48 - and 72 -hour samples proceed at a continually increasing rate. When the stationary state is reached, at 96 hours, the sample still takes up a considerable amount of oxygen, but the rate of uptake is constant, as it is in the I20- and 144-hour samples (allowing for irregularities due to the larger error in reading the manometers when the rate is so small).

The 96-hour and subsequent samples therefore resemble the glucose suspensions, showing a constant rate of oxygen uptake associated with an absence of bacterial growth; in the samples taken when the bacteria are actively growing, the oxygen is absorbed at a continuously increasing rate, as in the alanine suspensions. 


\section{SHAPE OF THE CURVE OF OXYGEN UPTAKE}

The 2-hour experimental period used in the earlier experiments is too short to estimate the shape of the rising curve obtained from samples taken in the logarithmic growth period, and for comparison with the suspension experiments a culture experiment was performed in which the readings were extended over 6 hours for each sample. The bacterial numbers, rates of oxygen uptake and the logarithm of

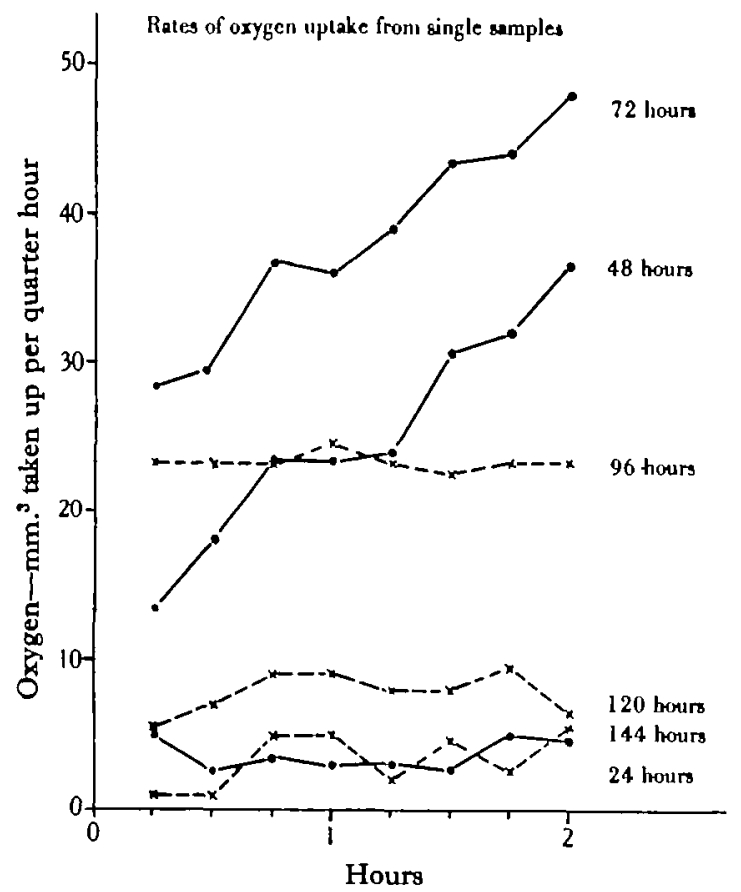

Fig. 4. Rates of oxygen uptake on successive days in a single expcriment.

the rates in the 48-hour sample are given in Table IV. The other samples gave similar results.

Table IV. 48-hour sample

\begin{tabular}{|c|c|c|c|c|}
\hline $\begin{array}{l}\text { Time from start } \\
\text { of readings } \\
\text { (hr.) }\end{array}$ & $\begin{array}{c}\text { Number of } \\
\text { bacteria } \\
\text { (millions per c.c.) }\end{array}$ & $\begin{array}{l}\text { Rate of oxygen } \\
\left(\mathrm{mm} .^{3} \text { per } \mathrm{hr} \text {. }\right)\end{array}$ & $\log _{10}$ rate & Difference \\
\hline $\begin{array}{c}0 \\
1-1 \\
I-1 \frac{1}{2} \\
1 \frac{1}{2}-2 \\
2-21\end{array}$ & $\begin{array}{l}602 \\
= \\
=\end{array}$ & $\begin{array}{l}\overline{66} \\
75 \\
86 \\
97\end{array}$ & $\begin{array}{l}\bar{I} \cdot \overline{820} \\
\mathrm{I} \cdot 875 \\
\mathrm{I} \cdot 935 \\
\mathrm{I} \cdot 987\end{array}$ & $\begin{array}{c}- \\
0.055 \\
0.060 \\
0.052\end{array}$ \\
\hline $\begin{array}{c}4-4 \frac{1}{8} \\
4-5 \\
5-5 \frac{1}{1} \\
5 \\
6\end{array}$ & $\begin{array}{l}\bar{z} \\
\overline{1} \\
1940\end{array}$ & $\begin{array}{l}165 \\
181 \\
183 \\
194\end{array}$ & $\begin{array}{c}2 \cdot 217 \\
2 \cdot 258 \\
2 \cdot 262 \\
2 \cdot 288 \\
-\end{array}$ & $\begin{array}{c}0.057 \\
0.041 \\
0.004 \\
0.026 \\
-\end{array}$ \\
\hline
\end{tabular}

$J E B \cdot x I V$ ii 
It will be seen that, for part of the six-hour readings, the rate of oxygen uptake is increasing logarithmically, as in the suspension experiments on alanine.

The readings taken for as long a period as 6 hours in a small sample do not, however, really represent what is happening in the original culture over the same period, as is shown by the bacterial numbers. In the Barcroft bottle, the numbers show a greater increase in 6 hours than is shown in 24 hours in the culture flask. A similar stimulation of bacterial growth in an apparatus which was shaken (in that case the Warburg apparatus) was observed by Wohlfeil \& Ewig (1935). As a method of discovering the real course of events in the original culture, it would be better to take samples at frequent intervals, and to observe them in the Barcroft apparatus for the shortest time which suffices to obtain an adequate manometer reading.

\section{EFFeCt OF REMOVAl of CELLS FROM a CULTURE}

As has already been stated in the first section of this paper, it is possible to think of the oxygen uptake of a growing culture as divided into two parts- "maintenance" respiration and "growth" respiration. A series of observations made during the whole growth cycle of a culture, as illustrated in Fig. 3, suggests that a growth respiration proportional to the rate of cell division is superimposed on a maintenance respiration which falls as the culture gets older; the two together giving a peak value for oxygen uptake in the middle of the logarithmic growth period, before the numbers of bacteria reach their maximum value.

A method of estimating the relative size of these two components of the total oxygen uptake was found in the removal of cells from a culture in the logarithmic growth period; this compared with a control culture under the same conditions should give cultures of the same age (and therefore presumably at the same level of maintenance respiration), but with different growth rates. Two such experiments were performed, one at $25^{\circ} \mathrm{C}$. and a second at $22^{\circ} \mathrm{C}$. Two conical flasks $A$ and $B$, each containing 60 c.c. of alanine medium, were inoculated at the same time from the same suspension; flask $A$ was used as a control. In the middle of the logarithmic growth period, 48 hours after inoculation in the first case, and 72 hours in the second, samples were taken from both $A$ and $B$ for the estimation of bacterial numbers and oxygen uptake. Immediately afterwards, half the contents of flask $B$ were removed, filtered through a Pasteur-Chamberland $\mathrm{L}_{3}$ candle to remove all bacterial cells, and replaced. Six hours later, and again 24 hours later, further determinations of bacterial numbers and the oxygen uptake during 2 hours were performed on samples from both $A$ and $B$. The results are given in Table $\mathrm{V}$.

It will be seen that the samples taken shortly after the removal of cells from flask $B$ (at 54 and 78 hours respectively), show an increased oxygen uptake, relative to the number of cells present, as compared with samples from flask $A$. It will also be seen that the growth rate, as judged by the amount of growth recorded I 8 hours later, is higher in flask $B$ than in the control. Assuming that the maintenance respiration per 1000 million cells is the same in cultures of the same age, and assuming that growth in both cultures is proceeding logarithmically, it is possible to calculate the approximate values of maintenance and growth respiration in both 
cases, for the samples taken at 54 and 78 hours (the next sampling after the removal of cells), since the total oxygen uptake is known in both cases.

Table V. Effect of removal of cells

\begin{tabular}{|c|c|c|c|c|c|c|}
\hline \multirow{2}{*}{$\begin{array}{l}\text { Hours } \\
\text { after } \\
\text { inocu- } \\
\text { lation }\end{array}$} & \multicolumn{2}{|c|}{$\begin{array}{l}\text { Bacteria (millions } \\
\text { per c.c.) }\end{array}$} & \multicolumn{2}{|c|}{$\begin{array}{c}\text { Oxygen uptake } \\
\text { (mm. in } 2 \text { hours) }\end{array}$} & \multicolumn{2}{|c|}{$\begin{array}{l}\text { Uptake per hour per } \\
\text { roo million cells }\end{array}$} \\
\hline & A & B & A & B & A & B \\
\hline \multicolumn{7}{|c|}{ Exp. I $\left(25^{\circ}\right.$ C. $)$} \\
\hline $\begin{array}{r}\circ \\
48\end{array}$ & $\begin{array}{r}11 \\
864\end{array}$ & $\begin{array}{r}11 \\
* 050\end{array}$ & $\overline{162}$ & $\overline{82}$ & $\overline{3 I}$ & $\overline{32}$ \\
\hline 50 & - & 470 & - & - & - & - \\
\hline 54 & 916 & 564 & 246 & 172 & 45 & $5 \mathrm{I}$ \\
\hline 72 & 1332 & I 192 & 207 & 264 & 26 & 37 \\
\hline \multicolumn{7}{|c|}{ Exp. $2\left(22^{\circ} \mathrm{C}.\right)$} \\
\hline $\begin{array}{r}0 \\
72\end{array}$ & $\begin{array}{r}4 \\
616\end{array}$ & $\begin{array}{r}4 \\
-50\end{array}$ & $\overline{112}$ & $\overline{101}$ & $\overline{30}$ & $\overline{20}$ \\
\hline 78 & 738 & $\begin{array}{r}500 \\
322\end{array}$ & $\begin{array}{l}122 \\
127\end{array}$ & 93 & $\begin{array}{l}30 \\
29\end{array}$ & 48 \\
\hline 96 & 934 & 906 & 230 & 205 & $4 I$ & 38 \\
\hline
\end{tabular}

- Immediately after this count, half the cells in $B$ were removed.

\section{Experiment I}

In culture $A$ there are 916 million cells per c.c. at 54 hours after inoculation, and 1332 million at 72 hours. By interpolation an estimate of the growth during the 2 hours from $54-56$ hours, when the oxygen uptake was being measured, gives a rate of growth of 20 million cells per hour-2.I per cent of the calculated mean value ( 935 million). Similarly in culture $B$, starting with 564 million cells per c.c. at 54 hours, the growth rate over the next 2 hours is estimated at 23.5 million cells per hour-4 per cent of the calculated mean value ( 588 million). The total oxygen uptake from 3 c.c. of culture during the period from $54^{-56}$ hours after inoculation is $246 \mathrm{~mm} .^{3}$ in the $A$ sample, and $172 \mathrm{~mm} .^{8}$ in the $B$ sample.

Assuming that

$x=$ maintenance respiration in $\mathrm{mm} .{ }^{8}$ per hour per 1000 million cells,

$y=$ growth respiration per I per cent growth,

we can then derive two equations in $x$ and $y$ from the data obtained from $A$ and $B$ respectively.

From $A$ we have

$$
\left(x \times 2 \times \frac{3 \times 935}{1000}\right)+(y \times 2 \cdot 1)=246
$$

and from $B$

$$
\left(x \times 2 \times \frac{3 \times 588}{1000}\right)+(y \times 4)=172
$$

On solving these equations we obtain values for $x$ and $y$ as follows:

$$
\begin{aligned}
& x=41 \cdot 4, \\
& y=6 \cdot 60 .
\end{aligned}
$$




\section{Experiment II}

On considering the data derived from the observations made from $78-80$ hours after inoculation in the second experiment, the growth rate in flask $A$ during this period is estimated at Io millions per hour, or $1 \cdot 34$ per cent of a calculated mean value of 748 million cells per c.c.; and in $B$ it is estimated at 20 millions per hour, 5.89 per cent of the calculated mean value (34I millions per c.c.). From these figures, and the values obtained for the total oxygen uptake, we obtain the following equations:

$$
\begin{aligned}
& 4 \cdot 49 x+1 \cdot 34 y=127 \\
& 2 \cdot 05 x+5 \cdot 89 y=93
\end{aligned}
$$

The values of $x$ and $y$ which fit both these equations are

$$
\begin{aligned}
& x=26 \cdot 3, \\
& y=6 \cdot 63 .
\end{aligned}
$$

Though these values of $x$ and $y$ are approximate only, it is interesting that the same value for $y$ should be obtained in both experiments, and that $x$, the maintenance respiration, should be smaller in experiment II, where the culture is older than in experiment I. Incomplete though these experiments are, they yet suggest a means of separating the effect of cell division on metabolism from the effect of other factors which change during the life of a culture in a limited volume of medium.

\section{DISCUSSION}

The most salient points that emerge from the results obtained on the course of oxygen uptake during a growth cycle in a culture are two in number. Firstly, the peak in oxygen uptake per cell occurring at 48 hours after inoculation (cf. Martin, I932); and secondly the rapid drop in oxygen uptake in successive samples taken after the numbers of bacteria had reached their highest point. It is not possible, from the data obtained, to say whether the smallness of the oxygen uptake in the week-old culture is simply caused by exhaustion of the substrate, or whether other causes contribute to this effect.

The results of both sets of experiments show a very marked difference between growing bacteria and bacteria in a stationary state. In the stationary states observed, i.e. suspensions supplied with glucose but no nitrogen, and cultures which had reached their maximum density, oxygen was absorbed, sometimes in considerable quantity, at a constant rate. In suspensions supplied with nitrogen as well as carbon, and in cultures in the logarithmic growth phase, the rate of oxygen uptake increased continuously during the period of observation. It might be expected that, as the numbers of bacteria present are increasing from moment to moment, the oxygen uptake would also increase proportionately to the increase in numbers; but the results of the suspension experiments show that the increase in oxygen uptake was greater in proportion than the increase in bacterial numbers. This led to the supposition that the respiration of growing bacteria could be divided into "maintenance" and "growth" respiration, the former furnishing enough energy 


\section{Oxygen Uptake of Suspensions and Cultures of a Free-living Bacterium 169}

to keep the cell alive, and the latter the extra energy required for cell division. The effect of removing cells by filtration from a culture in the logarithmic growth phase is to increase both the growth rate and the oxygen uptake per cell. Analysis of two such experiments suggests that growth respiration, per unit of growth, is constant during this logarithmic period, and that the maintenance respiration per cell falls as the culture grows older.

It may be of interest to note that the inverse relation between bacterial numbers and respiration per cell, which was observed in an earlier series of experiments on carbon dioxide output (Meiklejohn, 1932), did not hold good for the experiments reported in the present paper. A similar inverse relation, between bacterial numbers and oxygen uptake, was observed by Wohlfeil (1930); in both cases, the more bacteria present in a culture, the lower the respiration per cell; this relation was independent of the age of the culture. Both my former experiments, and those of Wohlfeil, used very different techniques to that employed in the present study; in both methods, air was bubbled comparatively slowly through a stationary flask. In a later paper, Wohlfeil \& Ewig (1935) state that they find no evidence of this inverse relation in a series of experiments performed with the Warburg apparatus, which resembles the Barcroft apparatus in that the experimental material is shaken, and kept under conditions of maximum air supply. Similarly, the results reported in the present paper give no indication of an inverse relation between bacterial numbers and oxygen uptake per cell.

I should like to express my thanks to $\mathrm{Mr} \mathrm{D}$. Ward Cutler, in whose department this work was carried out, for his constant help and encouragement.

\section{SUMMARY}

1. The oxygen uptake of pure cultures and suspensions of a free-living bacterial species has been measured at $26^{\circ} \mathrm{C}$.

2. At this temperature, liquid cultures reach the maximum stationary phase of growth about 96 hours after inoculation.

3. The greatest total oxygen uptake was observed in samples taken from cultures 72 hours after inoculation, and the greatest uptake per cell at 48 hours after inoculation. The oxygen uptake in cultures which have reached the stationary state falls off rapidly, at each successive sampling, to a very low value.

4. In suspensions deprived of nitrogen, and showing no growth, and in cultures in the stationary phase, oxygen uptake proceeds at a constant rate.

5. In both suspensions and cultures, where active growth is taking place, the rate of oxygen uptake rises continuously; after a preliminary period of adjustment this rise is logarithmic.

6. The rise in oxygen uptake in a growing suspension is proportionately greater than the rise in bacterial numbers.

7. It is suggested that the oxygen uptake of a growing culture can be divided into two parts; "maintenance" respiration and "growth" respiration, and a technique is outlined for estimating the amount of oxygen uptake due to each factor. 


\section{REFERENCES}

Bergey, D. (1934). Manual of Determinative Bacteriology, 4th ed. Balliere, Tindall and Cox.

Burk, D. \& Lineweaver, H. (1930). 7. Bact. 19, $3^{89}$.

Dixon, M. (1934). Manometric Methods. Cambridge Univ. Press.

Martin, D. S. (1932). F. gen. Physiol. 15, 691.

Meiklejohn, J. (1932). Ann. appl. Biol. 19, 584.

WALKer, H. H. \& WinsLow, C. E. A. (1932). J. Bact. 2A, 209.

Walker, H. H., Winslow, C. E. A., Huntington, E. \& Mooney, M. G. (I934). F. Bact. 27, 303.

WoHLFEIL, T. (1930). Zbl. Bakt. Abt. I, 117, 202.

WoHLfBIL, T. \& EwIG, W. (1935). Zbl. Bakt. Abt. I, 133, 4 I9. 